\title{
Communication and access to information in assessing the quality of multiprofessional care of patients
}

\author{
Comunicação e acesso a informações na avaliação da qualidade de assistência \\ multiprofissional a pacientes internados
}

Leny Vieira Cavalheiro ${ }^{1}$, Paola Bruno de Araújo Andreoli², Nadia Sueli de Medeiros ${ }^{3}$, Telma de Almeida Busch Mendes ${ }^{4}$, Roselaine Oliveira ${ }^{5}$, Júnia Jorge Rjeille Cordeiro ${ }^{6}$, Rejane Augusta de Oliveira Figueiredo ${ }^{7}$, Anna Margherita Toldi Bork ${ }^{8}$

\begin{abstract}
Objective: To assess the quality of a multiprofessional healthcare model for in-hospital patients by means of two performance indicators (communication and knowledge about the case). Methods: A cross-sectional study assessed the knowledge that professionals had about the clinical information of patients and the use of communication strategies by the team. Healthcare professionals were interviewed during their work period. Seven occupational categories were interviewed. A total of 199 medical charts were randomly selected for interviews, and 312 professionals of different categories were interviewed. The sample comprised mostly nurses and physical therapists in the charts that were interviewed. Results: There were no statistically significant differences between the expected performing model group and the under-performing model group for sex, location and job. In the under-performing model group, a larger number of professionals correlated with less knowledge. Communication was improved when nurses had the relevant information about interdisciplinary care $(97.4 \%)$, appropriate use of the Plan of Care form $(97.0 \%)$, and formalized discussions with physicians (88.2\%). In the expected performing model group, it was observed that the higher the number of healthcare professionals involved, the higher the communication levels. Conclusions: This model of care based on case knowledge and multiprofessional team communication performance indices allowed to assess quality of care. This assessment is measurable and there is the possibility of establishing the quality of care delivered.
\end{abstract}

Keywords: Interprofessional relations; Patient care team; Interdisciplinary communication; Inpatients; Quality of health care

\section{RESUMO}

Objetivo: Avaliar a qualidade de um modelo de assistência a pacientes internados por meio de dois índices de desempenho (comunicação e conhecimento do caso) das equipes multiprofissionais. Métodos: Foi realizado um corte transversal para avaliação do conhecimento dos profissionais a respeito das informações clínicas do paciente e 0 uso de estratégias de comunicação intraequipe. Foi utilizado o formato de entrevistas feitas com profissionais durante o período de trabalho. Sete categorias profissionais foram entrevistadas e foram sorteados para entrevista 199 prontuários. Foram avaliados 312 profissionais das diversas categorias. A amostra foi caracterizada pela predominância do envolvimento dos profissionais de enfermagem $e$ fisioterapia nos prontuários entrevistados. Resultados: Não houve diferenças estatisticamente significativas entre os grupos do modelo de desempenho esperado e do modelo de desempenho abaixo do esperado para as variáveis: sexo, situação e cargo dos profissionais. No grupo modelo de desempenho abaixo do esperado, evidenciou-se que quanto maior o número de profissionais envolvidos, menor o grau de conhecimento. A comunicação foi melhor quando o enfermeiro teve as informações relevantes sobre a assistência interdisciplinar $(97,4 \%)$, utilizou de forma adequada o impresso denominado Plano Assistencial $(97,0 \%)$ e formalizou a discussão com o médico $(88,2 \%)$. No grupo do modelo de desempenho esperado, evidenciou-se que

\footnotetext{
Study carried out at Department of Care Practice, Quality and Safety - Sociedade Beneficente Israelita Brasileira Albert Einstein - SBIBAE- São Paulo (SP), Brazil.

${ }^{1}$ Physical therapist; Master's degree in Rehabilitation; Consultant for Multiprofessional Care Practice at Sociedade Beneficente Israelita Brasileira Albert Einstein - SBIBAE, São Paulo (SP), Brazil.

${ }_{2}^{2}$ Psychologist; PhD in Health Sciences; Manager of the Department of Care Practice, Quality and Safety at Sociedade Beneficente Israelita Brasileira Albert Einstein - SBIBAE, São Paulo (SP), Brazil.

${ }^{3}$ Nurse; Nursing Coordinator at Hospital Israelita Albert Einstein - HIAE, São Paulo (SP), Brazil.

${ }^{4}$ Physical therapist; Master's degree in Gerontology of Hospital Israelita Albert Einstein - HIAE, São Paulo (SP), Brazil.

${ }^{5}$ Dietitian; Analyst of Multiprofessional Care Practice at Sociedade Beneficente Israelita Brasileira Albert Einstein - SBIBAE, São Paulo (SP), Brazil.

${ }^{6}$ Occupational therapist; Master's degree in Health Sciences and Consultant for Multiprofessional Care Practice at Sociedade Beneficente Israelita Brasileira Albert Einstein - SBIBAE, São Paulo (SP), Brazil.

${ }^{7}$ Statistitian, Master's degree in Statistics and Consultant for the Multiprofessional Care Practice at Sociedade Beneficente Israelita Brasileira Albert Einstein - SBIBAE, São Paulo (SP), Brazil.

${ }^{8}$ Nurse; Master's degree in Effectiveness in Evidence-based Healthcare and Director of the Department of Care Practice, Quality and Safety at Sociedade Beneficente Israelita Brasileira Albert Einstein SBIBAE, São Paulo (SP), Brazil.

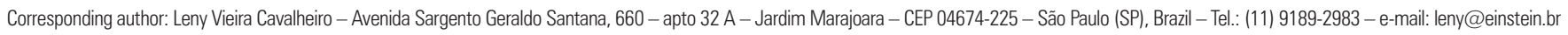

Received on Apr 15, 2009 - Accepted on Jun 9, 2010
} 
quanto maior o número de profissionais envolvidos, maior o grau de comunicação. Conclusões: Neste modelo assistencial, baseado no desempenho dos índices do conhecimento do caso e comunicação da equipe multiprofissional, pôde-se avaliar a qualidade da assistência. Portanto, essa avaliação é mensurável e é possível determinar o nível de qualidade da assistência prestada.

Descritores: Relações interprofissionais; Equipe de assistência ao paciente; Comunicação interdisciplinar; Pacientes internados; Qualidade da assistência à saúde

\section{INTRODUCTION}

Care of inpatients is a complex process requiring an organized work dynamics from the team. The care process involves a context of clinical information for treatment decision-making and a team communication context to effectively treat patients.

The medical literature frequently relates quality of care with safety, underlining the role of communication among team members. Some issues include difficulty in accessing information in medical charts, information about treatment, and communication failures, especially about medication $^{(1)}$.

Communication among teams and knowledge about cases have the highest impact on continuum of care and prompt process organization. The diversity and number of healthcare professionals accessing patients increase the possibility of communication failures about relevant and risky aspects ${ }^{(2)}$. A single patient in the hospital may receive care from a physician, a nurse, a nutritionist, or several other healthcare professionals, such as occupational therapists, psychologists and physical therapists. These professionals comprise the multiprofessional team. The connection of information generated by these professionals is often fragmented ${ }^{(3)}$.

Such risks may be minimized when a care model facilitates good interdisciplinary collaboration and effective communication focusing on error prevention and improved care $^{(4)}$.

So,theproposedcaremodelisbasedontheassumptions that nurses are care bedside information managers, and that there are formal communication channels among nurses, physicians and the multidisciplinary team.

\section{OBJECTIVE}

To assess the quality of a care to inpatients by applying two performance indices of multiprofessional teams.

\section{METHODS}

The idea of designing a care model based on knowledge about each case and team communication has made it possible to observe and analyze the performance of multidisciplinary teams during care.

Performance was measured using a statistical index based on weighed response points to interview questions, as follows: yes ( 2 points), partially ( 1 point), and no ( 0 points). The index was statistically generated ranging from 0 to $100 \%$ to establish a minimum performance cutoff.

A cross-sectional study was carried out to assess the knowledge that professionals had about patient medical information and the use of team communication strategies. The interviews comprised 199 medical charts picked out at random.

Professionals were interviewed during their work periods; the inclusion criterion was that each had to be on duty for at least one hour. Professionals were allowed to check their notes about patients in the charts or their personal records. The multiprofessional team members interviewed were: nurses, physical therapists, speech therapists, psychologists, pharmacists, social workers, and occupational therapists.

A stratified random sampling method was applied; the sampling unit was the number of discharges/referrals of inpatients in each hospital unit; all professionals involved with each patient were interviewed. A 95\% confidence level and a $7 \%$ sampling error were used for calculations. Beds were chosen randomly in each unit, based on a randomization table. An inclusion criterion was that patients had to have been admitted into each unit for at least 24 hours and were not scheduled for discharge in the next 24 hours.

Three data gathering tools were used: a) gold standard medical information instrument, b) gold standard model assumption instrument (team communication), and c) data gathering instrument according to knowledge about the case and team communication.

Establishing standard and comprehensive information about what should be known about a given case includes important items such as diagnosis, reason for hospital admittance, planned daily care, therapeutic plan, altered tests/exams, and the discharge plan. Communication could be tested in this model if professionals received information about cases from the previous on duty professional, if nurses received relevant information about interdisciplinary care, if the plan of care form was used and updated, and if there were any records of discussion between physicians and nurses about the patient's case.

Each question in the instrument consisted of answers requiring yes, partial or no answers; scoring was 0 for a 'no' answer, 1 for a 'partial' answer, and 2 
for a 'yes' answer. The mean scores for each question were converted into a 0 to 100 scale, thereby composing the knowledge and understanding indices used for subsequent analyses ${ }^{(5)}$.

\section{Statistical analysis}

Based on the performing index cutoff points (knowledge about the case and team communication) (85\%), two groups were established for comparison purposes, as follows: the expected performing model group (over $85 \%$ ), and an underperforming model group (below $85 \%)$. Results are presented according to the differences for each index.

The $\chi^{2}$ test or Fisher's exact test $(\mathrm{F})$, if necessary, were applied for comparing qualitative variables. Student's $t$ test was applied for comparing quantitative variables between two independent samples. The significance level for all tests was set at $5 \%$.

\section{RESULTS}

There were 312 interviewees in 7 categories of the 199 medical records, which consisted mostly of nurses and physical therapists (Table 1); most professionals worked full time (Table 2) at fixed care units (Table 3).

The index level to define whether professionals held quality information about each case and if there

Table 1. Description of the number of professionals in interviews per profession

\begin{tabular}{lcc}
\hline Occupational category & $\mathbf{n}$ & \% \\
\hline Nurse & 199 & 63.8 \\
Physical therapist & 80 & 25.6 \\
Speech therapist & 8 & 2.6 \\
Psychologist & 9 & 2.9 \\
Occupational therapist & 1 & 0.3 \\
Pharmacist & 12 & 3.8 \\
Social worker & 3 & 1.0 \\
\hline Total & 312 & 100.0 \\
\hline
\end{tabular}

Table 2. Distribution of professionals per professional level (junior, full, and senior) for each medical chart

\begin{tabular}{lcccccccc}
\hline \multirow{2}{*}{$\begin{array}{l}\text { Occupational } \\
\text { category }\end{array}$} & \multicolumn{2}{c}{ Junior } & \multicolumn{2}{c}{ Full } & \multicolumn{2}{c}{ Senior } & \multicolumn{2}{c}{ Total } \\
\cline { 2 - 9 } & $\mathbf{n}$ & $\%$ & $\mathbf{n}$ & $\%$ & $\mathbf{n}$ & $\%$ & $\mathbf{n}$ & $\%$ \\
\hline Nurse & 12 & 6.0 & 154 & 77.4 & 33 & 16.6 & 199 & 63.8 \\
Physical therapist & 1 & 1.3 & 62 & 77.5 & 17 & 21.3 & 80 & 25.6 \\
Speech therapist & 1 & 12.5 & 7 & 87.5 & & 0.0 & 8 & 2.6 \\
Psychologist & 5 & 55.6 & 2 & 22.2 & 2 & 22.2 & 9 & 2.9 \\
Occupational therapist & & 0.0 & 1 & 100.0 & & 0.0 & 1 & 0.3 \\
Pharmacist & 5 & 41.7 & 4 & 33.3 & 3 & 25.0 & 12 & 3.8 \\
Social worker & & 0.0 & 3 & 100.0 & & 0.0 & 3 & 1.0 \\
\hline Total & 24 & 7.7 & 233 & 74.7 & 55 & 17.6 & 312 & 100.0 \\
\hline
\end{tabular}

Table 3. Distribution of professionals according to their work situation (fully employed or temporary) for each medical chart

\begin{tabular}{lcccccc}
\hline \multirow{2}{*}{$\begin{array}{l}\text { Occupational } \\
\text { category }\end{array}$} & \multicolumn{2}{c}{ Temporary } & \multicolumn{2}{c}{ Fully employed } & \multicolumn{2}{c}{ Total } \\
\cline { 2 - 7 } & $\mathbf{n}$ & $\%$ & $\mathbf{n}$ & $\%$ & $\mathbf{n}$ & $\%$ \\
\hline Nurse & 55 & 27.6 & 144 & 72.4 & 199 & 100.0 \\
Physical therapist & 18 & 22.5 & 62 & 77.5 & 80 & 100.0 \\
Speech therapist & 4 & 50.0 & 4 & 50.0 & 8 & 100.0 \\
Psychologist & 3 & 33.3 & 6 & 66.7 & 9 & 100.0 \\
Occupational therapist & 0 & 0.0 & 1 & 100.0 & 1 & 100.0 \\
Pharmacist & 1 & 8.3 & 11 & 91.7 & 12 & 100.0 \\
Social worker & 0 & 0.0 & 3 & 100.0 & 3 & 100.0 \\
\hline Total & 81 & 26.0 & 231 & 74.0 & 312 & 100.0 \\
\hline
\end{tabular}

was team communication was $85 \%$. For the purpose of analysis, scores about knowledge and communication were categorized as:

- expected performing model: high knowledge level (communication) equal to or over $85 \%$ in the general score.

- underperforming model: low knowledge level (communication) below $85 \%$ in the general score.

There were no statistically significant differences between the groups "expected performing model" and "underperforming model" for the variables: sex, situation and professional job (Table 4).

The following evidence of knowledge about each patient's case was found:

- there was a higher percentage of patients with more than two professionals involved in the underperforming model group (knowledge level below $85 \%$ ), suggesting that more professionals involved in each case was correlated with lower knowledge levels (Table 4).

Analysis of the multiprofessional team communication among staff revealed the following:

- communication was improved when nurses had relevant information about interdisciplinary care, when they used the plan of care form adequately (writing and updating it), and when they formalized discussions with physicians. The plan of care form included data on knowledge about the case and team communication (Table 5);

- there were more patients cared for by a larger number of professionals (over two) in the expected performing model group (knowledge level over $85 \%$ ), suggesting that the level of communication was higher if there were more professionals involved in care. 
Table 4. Analysis of knowledge about each patient's case

\begin{tabular}{|c|c|c|c|c|c|c|}
\hline \multirow{3}{*}{\multicolumn{2}{|c|}{ Characteristics of professionals and knowledge about the case }} & \multicolumn{4}{|c|}{ General knowledge } & \multirow{3}{*}{ p value } \\
\hline & & \multicolumn{2}{|c|}{$<85 \%$} & \multicolumn{2}{|c|}{$\geq 85 \%$} & \\
\hline & & $\mathbf{n}$ & $\%$ & $\mathbf{n}$ & $\%$ & \\
\hline & M & 9 & 37.5 & 69 & 39.4 & 0.856 \\
\hline \multirow[t]{2}{*}{ Nursing - Work situation } & temporary & 8 & 33.3 & 47 & 26.9 & \multirow{2}{*}{0.506} \\
\hline & Fully employed & 16 & 66.7 & 128 & 73.1 & \\
\hline \multirow{2}{*}{ Nursing - Professional level } & Full & 19 & 79.2 & 135 & 77.1 & \multirow[t]{2}{*}{0.919} \\
\hline & Senior & 4 & 16.7 & 29 & 16.6 & \\
\hline \multirow{2}{*}{$\begin{array}{l}\text { Has received information about the case from the previous on } \\
\text { duty professionals? (nurse) }\end{array}$} & No/partial & 1 & 4.2 & 3 & 1.7 & \multirow{2}{*}{0.422} \\
\hline & Yes & 23 & 95.8 & 172 & 98.3 & \\
\hline Has relevant information about multidisciplinary care? (nurse) & No/partial & 2 & 15.4 & 6 & 6.7 & $0.265(\mathrm{~F})$ \\
\hline Is the Plan of care form updated? (nurse) & Yes & 18 & 78.3 & 150 & 90.9 & $0.077(\mathrm{~F})$ \\
\hline \multirow[t]{2}{*}{ Is there any record of discussion with the physician? (nurse) } & No/partial & 9 & 39.1 & 37 & 22.3 & \multirow{2}{*}{0.078} \\
\hline & Yes & 14 & 60.9 & 129 & 77.7 & \\
\hline \multirow[t]{2}{*}{ Number of employees involved } & Up to 2 employees & 20 & 83.3 & 167 & 95.4 & \multirow{2}{*}{0.020} \\
\hline & More than 2 employees & 4 & 16.7 & 8 & 4.6 & \\
\hline \multirow[t]{2}{*}{ General communication } & $<85 \%$ & 17 & 70.8 & 106 & 60.6 & \multirow{2}{*}{0.332} \\
\hline & $\geq 85 \%$ & 7 & 29.2 & 69 & 39.4 & \\
\hline
\end{tabular}

F: Fisher's exact test.

Table 5. Analysis of multiprofessional team communication

\begin{tabular}{|c|c|c|c|c|c|c|}
\hline \multirow{3}{*}{\multicolumn{2}{|c|}{ Characteristics of professionals and knowledge about the case }} & \multicolumn{4}{|c|}{ General communication } & \multirow{3}{*}{ p value } \\
\hline & & \multicolumn{2}{|c|}{$<85 \%$} & \multicolumn{2}{|c|}{$\geq 85 \%$} & \\
\hline & & $\mathbf{n}$ & $\%$ & $\mathbf{n}$ & $\%$ & \\
\hline \multirow[t]{2}{*}{ Sex } & $\mathrm{F}$ & 75 & 61.0 & 46 & 60.5 & \multirow{2}{*}{0.950} \\
\hline & M & 48 & 39.0 & 30 & 39.5 & \\
\hline \multirow{2}{*}{ Nursing - work situation } & Temporary & 39 & 31.7 & 16 & 21.1 & \multirow{2}{*}{0.102} \\
\hline & Fully employed & 84 & 68.3 & 60 & 78.9 & \\
\hline \multirow[t]{3}{*}{ Nursing - professional level } & Junior & 6 & 4.9 & 6 & 7.9 & \multirow{3}{*}{0.397} \\
\hline & Full & 99 & 80.5 & 55 & 72.4 & \\
\hline & Senior & 18 & 14.6 & 15 & 19.7 & \\
\hline \multirow{2}{*}{$\begin{array}{l}\text { Has received information about the case from the previous on } \\
\text { duty professionals? (nurse) }\end{array}$} & No/partial & 3 & 2.4 & 1 & 1.3 & \multirow{2}{*}{$>0.999$} \\
\hline & Yes & 120 & 97.6 & 75 & 98.7 & \\
\hline \multirow[t]{2}{*}{ Has relevant information about multidisciplinary care? (nurse) } & No/partial & 6 & 22.2 & 2 & 2.6 & \multirow{2}{*}{$0.004(F)$} \\
\hline & Yes & 21 & 77.8 & 74 & 97.4 & \\
\hline \multirow[t]{2}{*}{ Is the Plan of care form in use? (nurse) } & No/partial & 7 & 6.3 & 0 & 0.0 & \multirow{2}{*}{$0.043(F)$} \\
\hline & Yes & 105 & 93.8 & 76 & 100.0 & \\
\hline \multirow[t]{2}{*}{ Is the Plan of care form updated? (nurse) } & No/ partial & 17 & 15.2 & 3 & 3.9 & \multirow{2}{*}{0.014} \\
\hline & Yes & 95 & 84.8 & 73 & 96.1 & \\
\hline \multirow[t]{2}{*}{ Is there any record of discussion with the physician? (nurse) } & No/ partial & 37 & 32.7 & 9 & 11.8 & \multirow{2}{*}{0.001} \\
\hline & Yes & 76 & 67.3 & 67 & 88.2 & \\
\hline \multirow[t]{2}{*}{ Number of employees involved } & Up to 2 employees & 121 & 98.4 & 66 & 86.8 & \multirow{2}{*}{$0.001(F)$} \\
\hline & More than 2 employees & 2 & 1.6 & 10 & 13.2 & \\
\hline \multirow[t]{2}{*}{ General knowledge } & $<85 \%$ & 17 & 13.8 & 7 & 9.2 & \multirow{2}{*}{0.332} \\
\hline & $\geq 85 \%$ & 106 & 86.2 & 69 & 90.8 & \\
\hline
\end{tabular}

F: Fisher's exact test. 


\section{DISCUSSION}

According to Leonard et al., it is important to measure the communication among professionals of different areas, as well as continuity of information between professionals on duty in each specialty ${ }^{(6)}$. The results of this paper also revealed that communication among professionals define the quality of information and, consequently, the quality of care.

Healthcare institutions are organizing and learning about their quality of care, such as the Australian healthcare system, that has undertaken discussions on healthcare performance with the Australian Council for Safety and Quality in Health Care. There is no similar specific approach about communication and quality indicators, but improvements along this line have aimed to improve the process of $\operatorname{care}^{(7)}$.

All professionals involved in patient care should focus on such information and define/decide the most appropriate management for each case.

An adequate index, as found in this study, is over $85 \%$. Our argument is that each professional should know and share the information with those who are involved in caring for each case for improved planning and increased benefits.

It is thus important to measure communication among professionals of different areas and to assure that information is passed on from one to another person on duty within each discipline.

Care of patients also permeates the therapeutic interactions among the professionals involved. Improved communication and common understanding and objectives for therapy improve the clinical results ${ }^{(8)}$.

The care model adopted by each healthcare institution requires communication, efficiency, and technical effectiveness on the part of professionals dealing with a case; this yields harmonious understanding and improved patient care. Interpersonal relationships directly affect this process ${ }^{(9)}$.

The outcomes presented in this study are similar to those of other authors who investigated quality of care, pointing out the three factors that directly affect healthcare, namely: poor records in patient charts, continuum of care, and team communication ${ }^{(1)}$. As in the present study, these authors propose quality of care pillars, which are knowledge about cases, knowledge about care, and effective team communication among those who are dealing with the case.

Several teams have adopted information methods about cases and team communication, as the present case, to assess quality of care ${ }^{(6)}$.

On the other side, periodical evaluation of this performing index is needed to assess team performance. This is an important step for monitoring care team actions or goals.

\section{CONCLUSIONS}

The quality of care can be assessed in this model based on the performance of case knowledge and multiprofessional team communication indices. The assessment is measurable and makes it possible to establish the level of quality of care.

\section{REFERENCES}

1. Dean JE, Kamisha AH, Escoto H, Lawson R. Using a multi-method, user centred, prospective hazard analysis to assess care quality and patient safety in a care pathway. BMC Health Serv Res. 2007;7(89):1-10.

2. Bohlman LN, Panzer AM, Kindig DA. Health literacy: a prescription to end confusion. Washington: National Academy of Sciences; 2004.

3. Nutbeam D. Health literacy as a public health goal: a challenge for contemporary health education and communication strategies into the $21^{\text {st }}$ century. Health Promotion International. 2000;15(3):259-67.

4. Sirota T. Nurse Physician relationships improving or not. Nursing. 2007;37(1):52-6.

5. McDowel I, Newell C. Measuring health: a guide to rating scales and questionnaires. 2nd ed. New York: Osford Press; 1996.

6. Leonard M, Graham S, Bonacum D. The human factor: the critical importance of effective teamwork and communication in providing safe care. Qual Saf Health Care. 2004;13(1):85-90.

7. Australian Council for Safety and Quality in Health Care, Open Disclosure Standard: A National Standard for Open Communication in Public and Private Hospitals following and Adverse Event; 2003. Available from: www. safetyandquality.com

8. Sheehan D, Robertson L, Ormond T. Comparison of language used and patterns of communication in interprofessional and multidisciplinary teams. Journal of Interprofessional Care. 2007;21(1):17-30.

9. Mayer M, Costenaro RGS, Mota MS, Fossá MIT. A importância da comunicação organizacional na atuação da equipe multiprofissional de saúde. [Internet] [s.d.] [cited 2010 maio 15] Available from: encipecom.metodista.br/.../GT1__A_importancia_da_comunicacao-varios.pdf 